Jurnal Ekonomi dan Industri

e-ISSN: 2656-3169

Volume 21, No.3, September-Desember 2020

p- ISSN: 0853-5248

\title{
PERPUTARAN PIUTANG DAN PERPUTARAN PERSEDIAAN TERHADAP KUALITAS LABA PERUSAHAAN OTOMOTIF DAN KOMPONEN YANG TERDAFTAR DI BURSA EFEK INDONESIA PERIODE 2016-2019
}

\author{
Ayu Puspitaningtyas *) \\ *) Dosen Program Studi Manajemen FE UNKRIS \\ Alamat: Kampus UNKRIS, Jatiwaringin Jakarta Timur \\ Email : ayupuspitaningtyas@unkris.ac.id
}

\begin{abstract}
This study aims to find out how the simultaneous influence receivabley turnover and inventory turnover on the earning quality of automotive and componens companies This research uses purposive sampling in taking data. The data collected will be analyzed using multiple linear analysis. The result of this research is (1) there is negative significant influence from receivable turnover variable to earning quality, (2) there is positif significant influence from inventory turnover variable to earning quality, (3) there is a significant effect of receivable turnover and inventory turnover value addedon earning quality simultaneously.
\end{abstract}

Keywords: Receivabley turnover, inventory turnover, and earning quality

\section{PENDAHULUAN}

Fluktuatifnya dunia perekonomian menyebabkan perusahaan harus mampu bersaing guna kelangsungan hidup usaha. Agar perusahaan tetap dapat berkelanjutan tentu harus menghasilkan laba. Namun untuk memikat calon investor agar mau menginvestasikan dananya, suatu perusahaan harus menyajikan laba yang berkualitas.

Laba biasanya tersaji didalam laporan keuangan perusahaan. Namun terkadang perusahaan menyajikan laba yang tidak sesuai kenyataan tetapi hanya untuk memperoleh dana dari calon investor maupun kreditor. Agar terhindar pengambilan keputusan yang salah maka laba perusahaan harus dianalisi terlebih dahulu. Terdapat beberapa cara untuk menganalisi laba yang umum digunakan oleh investor antara lain : return on investment (ROI), return on assets (ROA), return on equity (ROE), earning per share (EPS), kualitas laba dan masih banyak lainnya.

Herwiyanti dan Baridwan (2008), menyatakan bahwa kualitas laba yang baik akan meningkatkan expected future earnings, hal ini akan menurunkan resiko kesalahan, sehingga laba yang berkualitas baik akan lebih informatif di pasar modal. Piter Tiong (2017) menyatakan laba yang diperoleh bukan merupakan ukuran bahwa perusahaan tersebut telah bekerja secara efisien. Tingkat efisiensi dapat diketahui dengan cara membandingkan antara laba dengan modal kerja yang diinvestasikan oleh perusahaan. Untuk mencapai tujuan tersebut diperlukan adanya modal kerja. Jumlah modal kerja yang dimiliki harus disesuaikan dengan kebutuhan perusahaan agar tidak menimbulkan efek negatif terhadap perusahaan. Memiliki jangka waktu yang relatif pendek tentu menjadi hal yang diharapkan dari perputaran modal kerja.Komponen modal kerja yang dimaksud yakni kas, piutang dan persediaan.

Penjualan menjadi acuan untuk mengukur tingkat aktivitas perusahaan dalam bersaing merebut pasar, sehingga diperlukan kebijakan perusahaan guna meningkatkan 
jumlah penjualan. Kelonggaran perusahaan dalam hal penjualan secara kredit dapat menimbulkan peningkatan jumlah piutang perusahaan. Semakin besar volume piutang akan berdampak pada resiko gagal tagih. Oleh karena itu perusahaan pada umumnya mencadangkan dananya untuk meminimalisir resiko tersebut. Resiko tersebut juga dapat terealisir apabila perusahaan dengan segala kebijakannya mampu meningkatkan kecepatan perubahan piutang menjadi kas.

Persediaan juga memiliki pengaruh terhadap laba yang akan diperoleh perusahaan. Jika jumlah persediaan kurang, tentu akan mengganggu kelancaran aktivitas operasi perusahaan, sedangkan jika jumlah persediaan besar, maka akan menimbulkan beberapa resiko, seperti peningkatan biaya penyimpanan (gudang), penurunan harga, perubahan pola konsumsi atau kerusakan persediaan. Untuk menghindari hal tersebut maka manajemen harus dapat mengelola persedian dengan baik. Perputaran persediaan dapat menjadi alat yang digunakan perusahaan untuk mengukur tingkat efektivitas dalam persediaan.

Utami dan Dewi (2016) menyatakan bahwa receivable turnover berpengaruh signifikan terhadap profitabilitas, sedangkan Diana dan Santosa (2016) menyatakan bahwa receivable turnover tidak memiliki pengaruh yang signifikan terhadap profitabilitas. Utami dan Dewi (2016) menyatakan bahwa inventory turnover berpengaruh terhadap profitabilitas, sedangkan Sartika, Feranika dan Wahyudi (2015) menyatakan bahwa inventory turnover tidak memiliki pengaruh yang signifikan terhadap profitabilitas.

\section{LANDASAN TEORI}

\section{Kualitas Laba}

Schipper dan Vincent (2003) menyatakan bahwa laba berkualitas adalah laba yang memiliki kemampuan perdiktif, variabilitas dan laba yang persisten. Laba yang berkualitas adalah laba yang dapat mencerminkan kelanjutan laba (sustainable earning) dimasa depan, yang ditentukan oleh komponen akrual serta dapat mencerminkan kinerja keuangan perusahaan yang sesungguhnya (Yeni, 2013). Bellovary et al. (2005) mendefinisikan kualitas laba sebagai kemampuan laba dalam merefleksikan kebenaran laba perusahaan dan membantu memprediksi laba mendatang dengan mempertimbangkan stabilitas dan persistensi laba. Kualitas laba bergantung pada informasi laba yang relevan dalam membuat keputusan. Pemanfaatan informasi laba sebagai dasar dalam pengambilan keputusan berinvestasi oleh investor, ini menunjukkan kualitas laba tersebut. Quality of income ratio akan digunakan dalam mengukur kualitas laba.

\section{Perputaran Piutang}

Diana dan Santoso (2016) menyatakan bahwa account receivable turnover merupakan kemampuan dana yang melalui penjualan yang ada dalam piutang berputar berapakali dalam suatu periode. Periode perputaran piutang bergantung pada kondisi pembayaran kreditnya, semakin lama suatu periode perputaran piutang maka semakin lama periode terikatnya dana dalam piutang. Apabila tingkat account receivable turnover semakin besar maka dana yang diinvestasikan dalam piutang akan semakin kecil. Menurut Purnamasari dan Fitria (2015) mengatakan bahwa semakin singkat waktu debitur melakukan pelunasan piutang kepada perusahaan, maka semakin baik untuk kas perusahaan, sehingga kebutuhan kas akan modal kerja untuk membiayai aktiviatas operasi perusahaan dapat terpenuhi.

\section{Perputaran Persediaan}


Rahma (2011) dalam Sari dan Budiasih (2014) mengatakan bahwa, persediaan merupakan barang yang akan dijual kembali, baik diolah maupun tidak diolah dari perusahaan dan merupakan aset yang mengalami perputaran secara berkelanjutan. Fitri (2013) dalam Sari dan Budiasih (2014) menyatakan inventory turnover yang lambat menunjukkan semakin lama persediaan berada di perusahaan, sehingga dapat memperbesar biaya persediaan, dan akan menurunkan laba perusahaan. Menurut Diana dan Santoso (2016), inventory turnover menunjukkan kemampuan dana yang ada dalam persediaan dapat berputar dalam suatu periode. Berdasarkan pengertian tersebut dapat disimpulkan bahwa perputaran persediaan perusahaan terkait dengan profitabilitas perusahaan.

\section{Model Penelitian}

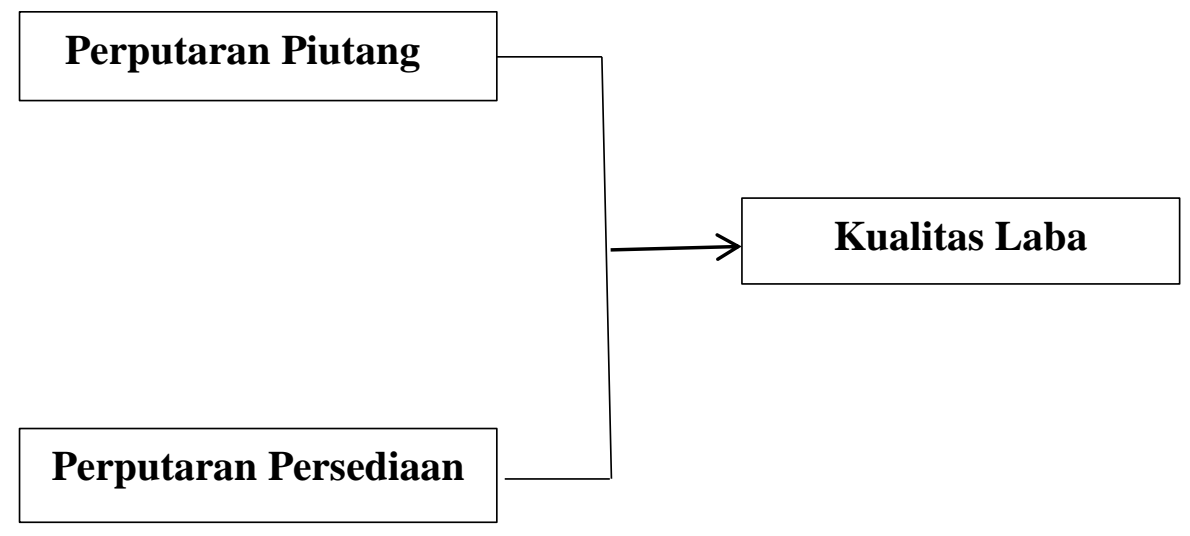

\section{Gambar-1: Model Penelitian}

\section{Hipotesis}

Hipotesis dalam penelitian adalah terdapat pengaruh perputaran piutang dan perputaran persediaan terhadap kualitas laba perusahaan secara bersama-sama.

\section{METODE PENELITIAN}

\section{Metode Pengumpulan Data}

Metode pengumpulan data yang digunakan dalam penelitian ini adalah data sekunder berupa data times series selama periode 2016-2019 dengan populasi sebanyak 11 perusahaan yang merupakan perusahaan dalam kelompok otomotif dan komponen yang terdaftar di Bursa Efek Indonesia. Sampel dipilih dengan teknik purposive sampling, yakni dalam menentukan anggota sampel secara khusus berdasarkan tujuan penelitian dan kesesuaian kriteria-kriteria yang telah ditetapkan penulis (Sugiyono, 2013). Adapun kriteria dalam pemilihan anggota sampel pada penelitian ini yakni : 1). Data perusahaan dapat diakses dengan lengkap. 2). Tidak mengalami rugi selama periode pengamatan

Berdasarkan kriteria tersebut terdapat 6 dari 11 perusahaan yang memenuhi kriteria, seperti terlihat dalam tabel-1. 
Tabel-1: Daftar Nama Perusahaan Sektor Otomotif dan Komponennya

\begin{tabular}{cll}
\hline No & \multicolumn{1}{c}{$\begin{array}{c}\text { Kode } \\
\text { Saham }\end{array}$} & \multicolumn{1}{c}{ Nama Perusahaan } \\
\hline 1. & ASII & PT Astra Indonesia, Tbk \\
2. & AUTO & PT Astra Otopart, Tbk \\
3. & BRAM & PT Indo Kordsa, Tbk \\
4. & GJTL & PT Gajah Tunggal, Tbk \\
5. & INDS & PT Indospring, Tbk \\
6. & SMSM & PT Selamat Sempurna, Tbk \\
\hline
\end{tabular}

\section{Metode Analisis Data}

Metode analisis dalam penelitian ini menggunakan analisis regresi linear berganda dengan persamaan:

$\mathrm{Y}=\mathrm{a}+\mathrm{b}_{1} \mathrm{X}_{1}+\mathrm{b}_{2} \mathrm{X}_{2}$

Keterangan :

$\mathrm{Y} \quad=$ Kualitas laba

$\mathrm{X}_{1} \quad=$ Perputaran piutang

$\mathrm{X}_{2} \quad=$ Perputaran persediaan

a $\quad=$ Konstanta

$\mathrm{b}_{1}, \mathrm{~b}_{2}=$ Koefisien regresi

\section{HASIL PENELITIAN DAN PEMBAHASAN}

\section{Analisis Hasil Penelitian}

Tabel-2: Perputaran Piutang dan Perputaran Persediaan terhadap Kualitas Laba

\begin{tabular}{lrcc}
\hline \multicolumn{1}{c}{ Variabel } & $\begin{array}{c}\text { Koefisien } \\
\text { Regresi }\end{array}$ & t-hitung & Signifikan \\
\hline Konstanta & 1,101 & 5,223 & 0,000 \\
Perputaran Piutang & $-0,130$ & $-2,672$ & 0,014 \\
Perputaran Persediaan & 0,091 & 2,092 & 0,049 \\
F-hitung = 3,731 & & & 0,041 \\
$\mathrm{R}^{2}=0,262$ & & & \\
\hline
\end{tabular}

Sumber: Data primer, diolah (2020)

Nilai $F_{\text {hitung }}$ sebesar 3,731 dengan nilai sig sebesar 0,041 sedangkan $F_{\text {tabel }}(\alpha=0,05$; $\mathrm{db}$ regresi $=2 ; \mathrm{db}$ residual $=21)$ adalah 3,47. Dengan kata lain, $\mathrm{F}_{\text {hitung }}=3,731>\mathrm{F}_{\text {tabel }}=3,47$ atau nilai sig sebesar $0,041<\alpha=0,05$ menghasilkan $\mathrm{H}_{0}$ ditolak dan $\mathrm{H}_{1}$ diterima, artinya secara bersama-sama perputaran piutang dan perputaran persediaan berpengaruh signifikan 
terhadap kualitas laba. Koefisien determinasi $\left(\mathrm{R}^{2}\right)$ sebesar 0,262, artinya kontribusi perputaran piutang dan perputaran persediaan terhadap kualitas laba sebesar 26,2\% sedangkan sisanya sebesar 73,8\% disumbangkan oleh variabel lain yang tidak diteliti.

Nilai $t_{\text {hitung }}$ antara variabel perputaran piutang dengan kualitas laba sebesar 2,672 sedangkan tabel pada taraf kesalahan $\alpha=5 \%$ dengan uji dua arah $(5 \% / 2=0,025)$ dan derajat bebasnya (df) adalah n-2 $=24-2=22$, dengan menggunakan tabel t-statistik dua arah akan diperoleh $t_{\text {tabel }}$ sebesar 2,074. Berdasarkan nilai $t_{\text {hitung }}$ dan $t_{\text {tabel }}$, dimana $t_{\text {hitung }}=2$, $672>\mathrm{t}_{\text {tabel }}=2,074$, dengan demikian $\mathrm{H}_{0}$ ditolak dan $\mathrm{H}_{1}$ diterima. Artinya perputaran piutang berpengaruh signifikan terhadap kualitas laba.

Nilai thitung antara variabel perputaran persediaan dengan kualitas laba sebesar 2,092 sedangkan $t_{\text {tabel }}$ pada taraf kesalahan $\alpha=5 \%$ dengan uji dua arah $(5 \% / 2=0,025)$ dan derajat bebasnya (df) adalah $n-2=24-2=22$, dengan menggunakan tabel t-statistik dua arah akan diperoleh $t_{\text {tabel }}$ sebesar 2,074. Berdasarkan nilai $t_{\text {hitung dan }} t_{\text {tabel }}$, dimana $t_{\text {hitung }}=2$, $092>t_{\text {tabel }}=2,074$, dengan demikian $\mathrm{H}_{0}$ ditolak dan $\mathrm{H}_{1}$ diterima. Artinya perputaran persediaan berpengaruh signifikan terhadap kualitas laba.

$$
\text { Persamaan Regresi Y = 1,101 - 0,130 }\left(\mathrm{X}_{1}\right)+0,091\left(\mathrm{X}_{2}\right)
$$

Konstanta $(\alpha)$ sebesar 1,101, hal ini menunjukkan bahwa nilai kualitas laba sebesar Rp 1,101 jika tanpa adanya perputaran piutang dan perputaran persediaan. Nilai koefisien regresi perputaran piutang sebesar $-0,130$, hal ini menunjukkan bahwa setiap kenaikan perputaran piutang sebesar 1\% akan menurunkan kualitas laba sebesar Rp 0,130, begitupula sebaliknya jika setiap penurunan perputaran piutang sebesar $1 \%$, maka akan meningkatkan kualitas laba sebesar Rp 0,130 dengan asumsi perputaran persediaan tidak berubah. Nilai koefisien regresi perputaran persediaan sebesar 0,091 , hal ini menunjukkan bahwa setiap kenaikan perputaran persediaan sebesar 1\%, maka akan menaikkan kualitas laba sebesar Rp 0,091, begitu juga sebaliknya jika setiap penurunan perputaran persediaan sebesar 1\%, maka akan menurunkan kualitas laba sebesar Rp 0,091 dengan asumsi perputaran piutang tidak berubah.

\section{Pembahasan}

Peningkatan atau penurunan perputaran piutang akan menurunkan atau menaikkan kualitas laba, hal ini dikarenakan kemampuan manajemen dalam mengelola piutang dengan kebijakan pemberian piutang kepada debitur. Fleksibelitas kebijakan piutang dan rata-rata tingkat kecepatan perubahan piutang menjadi kas merupakan beban bagi perusahaan dalam menghasilkan kualitas laba.

Peningkatan atau penurunan perputaran persediaan akan menaikkan atau menurunkan kualitas laba, hal ini dikarenakan kemampuan manajamen dalam mengelola persediaan. Jumlah rata-rata persediaan yang masih ada didalam gudang merupakan beben bagi perusahaan dalam menghasilkan kualitas laba.

\section{KESIMPULAN DAN SARAN}

\section{Kesimpulan}

Peningkatan atau penurunan perputaran piutang akan menurunkan atau menaikkan kualitas laba, sedangkan peningkatan atau penurunan perputaran persediaan akan menaikkan atau menurunkan kualitas laba. 


\section{Saran}

Perusahaan dapat meningkatkan kebijakan pengelolaan piutang dan persediaan untuk menekan beban perusahaan dalam menghasilkan kualitas laba.

\section{DAFTAR PUSTAKA}

Bellovary et. al. 2005. Earning Quality: It's Time to Measure and Report. New York Journal, Vol. 75, No. 11, hal 32-37.

Diana, Putri Ayu dan Santoso, Bambang Hadi (2016). Pengaruh Perputaran Kas, Piutang, Persediaan terhadap Profitabilitas pada Perusahaan Semen di BEI. Jurnal Ilmu dan Riset Manajemen. Vol 5 No.3, hal 1-18.

Fitri, Meria. 2015. Pengaruh perputaran Piutang Usaha dan Perputaran Persediaan terhadap Profitabilitas Perusahaan Otomotif dan Komponen yang Terdaftar di Bursa Efek Indonesia. Skripsi. Jurusan Manajemen. Fakultas Ekonomi Universitas Negeri Padang

Herwiyanti, Elianda dan Baridwan, Zaki. 2008. Pengaruh Kualitas Laba pada Yield Obligasi dengan Corporate Governance sebagai Variabel Pemoderasi. E-Jurnal Bisnis dan Akuntansi, Vol. 10, No. 2, hal, 59-68

Piter Tiong. 2017. Pengaruh Perputaran Piutang terhadap Profitabilitas pada Perusahaan PT Mitra Phinastika Mustika Tbk. E-Journal of Management \& Business. ISSN: 2598-8301, Vol 1, No 1, hal 1-25.

Purnamasari, Diah Ayu dan Astri Fitria. 2015. Pengaruh Perputaran Piutang dan Ukuran Perusahaan terhadap Profitabilitas Perusahaan Kimia. Jurnal Ilmu dan Riset Akuntansi. Vol. 4, No. 8, hal 1-15.

Rahma, Aulia. 2011. Analisis Pengaruh Manajemen Modal Kerja terhadap Profitabilitas Perusahaan (Studi Pada Perusahaan Manufaktur PMA dan PMDN yang Terdaftar di BEI periode 2004-2008). Skripsi Sarjana Jurusan Manajemen pada Fakultas Ekonomi Universitas Diponogoro, Semarang.

Sari, Ni Made Vironika dan I.G.A.N Budiasih. 2014. Pengaruh Debt to Equity Ratio, Firm Size, Inventory Turnover dan Assets Turnover pada Profitabilitas. E-Jurnal Akuntansi Universitas Udayana, ISSN : 2302-8556 Vol 6.No 2, hal. 261-273.

Sartika, Milda Unik, Feranika, Nungky Viana, dan Wahyudi, Koko Denik (2015). Rasio Aktivitas yang Mempengaruhi Profitabilitas Perusahaan pada Sektor Otomotif yang Terdaftar di Bursa Efek Indonesia. Majalah Ilmiah "DIAN ILMU”, Vol. 15, No.1, hal 75-89.

Schipper, K. dan Linda Vincent.2003. Earning Quality. Accounting Horizons, Vol 17 hal 97-110.

Sugiyono, P.D. 2015. Metode Penelitian : Kuantitatif, Kualitatif dan R\&D. Bandung. ALFABETA, CV.

Utami, Made Sri dan Dewi S, Made Rusmala (2016). Pengaruh Manajemen Modal Kerja terhadap Profitabilitas Perusahaan Manufaktur yang Terdaftar di Bursa Efek Indonesia”. E-Jurnal Manajemen Unud, Vol.5 No.6, hal 3476- 3503.

Wulansari, Yeni. 2013. Pengaruh Investement Opportunity Set, Likuiditas dan Leverage terhadap Kualitas Laba pada Perusahaan Manufaktur yang Terdaftar di BEI. Skripsi Jurusan Akuntansi Fakultas Ekonomi Universitas Negeri Padang. 